\title{
Psikolojik Tipler ve Jung Psikolojisi Üzerine Bir Değerlendirme
}

Cem GÜLCAN*

\begin{abstract}
Öz
Carl Gustav Jung, psiikolojinin otonom ve geçerli bir bilim dalı olmasını Sigmund Freud ve Alfred Adler ile birlikte sağlayan üç ünlü psikologdan birisidir. Bu makalede, Carl Gustav Jung'un ortaya koyduğu Analitik Psikoloji kuramı ve Psikolojik Tipler yaklaşımı üzerinde durulmuştur. Jung'un Psişe olarak adlandırdığı zihin içerisinde yer alan Persona, Ben, Gölge, Anima ve Animus gibi pek çok farklı ve işlevsel katman tartışılmıştır. Sonraki bölümde Jung'un 8'e ayırdığı insan tipolojisi, tarihe mal olmuş kişiler üzerinden yine Jung'un tasvirlerinden de uzaklaşmadan örneklendirmiş, yorumlanmış ve tanımlanmıştır. Bu çalışmanın, Analitik Psikoloji kuramı ile özellikle de Psikolojik Tipler yaklaşımı konusunda öğrencilere ve akademisyenlere kaynak olması amaçlanmıştır.
\end{abstract}

Anahtar Kelimeler: Carl Gustav Jung, Analitik Psikoloji, Psikolojik Tipler

\section{An Evaluation On Psychological Types and Jungian Psychology}

\begin{abstract}
Carl Gustav Jung is one of three famous psychologists who, together with Sigmund Freud and Alfred Adler, make psychology an autonomous and valid science. This article focuses on the Analytical Psychology theory and the Psychological Types approach put forward by Carl Gustav Jung. Many different and functional concept such as Persona, Self, Shadow, Anima and Animus, which are in the mind that Jung calls Psyche, have been discussed. In the next section, the human typology that Jung devoted to 8 is exemplified, interpreted and described over the people who have historically been kept away from the depictions of Jung. This study is intended to be a resource for students and academics, especially with the Analytical Psychology theory and the Psychology Types approach.
\end{abstract}

Keywords: Carl Gustav Jung, Analytical Psychology, Psychological Types

Geliş/Received: 06. 02. 2020

Kabul/Accepted: 26. 12. 2020

* Bu çalışma, insanlardan veri ve örnek toplamayı gerektiren, anket, inceleme, alan çalışması ve deney içeren araştırmalar 'kapsamına girmediğinden etik kurul onay belgesi gerektirmemektedir.

*Doktora Öğrencisi, Anadolu Üniversitesi Halkla İlişkiler ve Reklamcıllk Doktora Programı, cemgulcan26@gmail.com, D/0000-0003-0771-3030

(Makale türü: Derleme) 


\section{Cem GÜLCAN}

Psikolojik Tipler ve Jung Psikolojisi Üzerine Bir Değerlendirme

\section{Giriş}

Aristoteles, "Metafizik" kitabına: "Bütün insanlar doğal olarak bilmek isterler" cümlesiyle başlamaktadır. En azından bugün sahip olduğumuz bilimsel, felsefi, dini veya kültürel her türlü bilginin, atalarımızın "Doğal olarak bilmek" isteyen bölümünün, çevrelerini anlama çabaları sonucunda miras kaldığı bilinmektedir. Bu çabalar içerisinde, insanın kendisini etrafındaki diğer canlılardan farklı kılan şeyin ne olduğunu anlama çabası her daim önemli bir yer işgal etmiştir. İlk çağlarda buna sebep olanın, "Ruh” olduğu görüşü hem dini hem de felsefi açıdan genel anlamda tatmin edici bir cevap olarak kabul görmüştür. Günümüzde, insanın davranışlarını ve zihinsel süreçlerini anlama çabası olarak tanımlanan "Psikoloji” kelimesinin kökü de, eski Yunanca'da, Psyche (Ruh, Nefes) ve Logos (Düzenli söz, Bilgi) kelimelerinin birleşimine dayanmaktadır. Psikolojinin, felsefenin gövdesinden ayrılıp otonom bir bilim dalı olarak ortaya çıkması 19.yy'ın sonu, 20.yy'ın başlarına tekabül etmektedir. Böylelikle ruh kavramı, yerini zihin kavramına bırakarak pozitif bir anlam kazanıp yavaş yavaş bilim dünyasında kabul görür hale gelmiştir.

Carl Gustav Jung, psikolojinin günümüzdeki meşruiyetini kazanmasını sağlayan, Sigmund Freud ve Alfred Adler ile beraber üç isimden birisidir. İsviçre’nin küçük bir kasabasında papaz bir babanın oğlu olarak dünyaya gelen Jung, psikolojiye pek çok yeni kavram kazandırmıştır. En başta kolektif ve bireysel arketipler olmak üzere, "Persona, Aninma, Animus ve Gölge" gibi kavramları barındıran Analitik Psikoloji kuramı Jung psikolojisinin tümünü kapsayan bir çatı olarak ortaya konulmuştur. Jung, kendisini "Veliahtım" olarak nitelendiren Freud'un tüm diretmelerine rağmen, kendi öğretilerini Freud ile aralarının bozulması pahasına savunmuş ve çağının en popüler psikoloğu olmayı başarmıştır. Jungian psikoloji, tüm diğer yaklaşımlar içerisinde en kapsamlı ve bilinen model olmasının yanı sıra karmaşıklık ve belirsizlik yönünden oldukça eleştirilmiştir. Öyle ki psikolojinin içinden gelen bilim insanları hatta Jung özelinde çalışmalar yapanlar bile Jung'un ortaya attığı bazı kavramları aktarmakta, sınırlarını çizmekte güçlük çekmektedirler. Carl Jung’un kendisi de hayattayken bu durumun farkındaydı. İngilizce, Almanca, Latince bilmesi ve filoloji alanında da oldukça yetkin olmasına karşı Jung, bu karmaşıklığı bir zorunluluk olarak kabul etmiş, teorik anlamda derine inmenin başka bir yolu olmadığını savunmuştur. Bununla beraber Jung, kendi öğretilerinin günlük yaşama da katk1 sağlayabilmesi ve uygulanabilir olması için teorik psikolojinin yanında "Pratik Psikoloji" adını verdiği bir yaklaşım da ortaya koymuştur. Pratik psikoloji, özünde çeşitli betimlemelerle, sınıflandırmalarla, tanımlamalarla ve benzetmelerle insan zihninin yapısını anlaşılabilir hale getirmeyi amaçlayan bir yaklaşım olarak özetlenebilir. Daha önce de belirtildiği gibi zihin çok karmaşık bir yapıya sahiptir ve bir benzetme yapmak gerekirse siyah ile beyaz arasındaki grinin, 
binlerce tonu arasındaki ince farklılıklar gibi ayrıştırmak ve anlamak zordur. Pratik psikoloji, insan zihnini daha görünür kılmak için adeta gri yerine siyah ve beyazı kullanmaktadır.

Jung, her insanın birbirinden farklı olduğunu ve hiçbirinin tam olarak bir psikolojik tipe yüzde yüz uymadığını kabul ederek "Psikolojik Tipler" yaklaşımını ortaya atmıştır. Bu yaklaşım, bireyleri zihinsel açıdan sınıflandırmayı amaçlayan, en temelde "İçe Dönük Tip" ve "Dışa Dönük Tip" olmak üzere iki temel grup, toplamda 8 farklı sınıfın olduğu bir pratik psikoloji yaklaşımıdır.

Bir değerlendirme makalesi olan bu çalışmanın temel amacı Carl Gustav Jung'ın "Psikolojik Tipler" yaklaşımını betimlemeler ve örneklendirmelerle ortaya koymaktır. Elbette "Psikolojik Tipler" yaklaşımını anlayabilmek için Jung'un ortaya koyduğu diğer kavram ve yaklaşımların da üzerinde durulmuştur.

\section{Carl Gustav Jung'un Hayatı, Eğitimi ve Freud Etkisi}

Carl Gustav Jung, 26 Temmuz 1875 günü Protestan papazı bir babanın oğlu olarak İsviçre'nin kuzeydoğu bölgesinde Konstanz Gölünün kıyısında yer alan Kesswill Kasabasında dünyaya gelmiştir. Jung, ismini Basel şehrinin önde gelen hekimlerinden olan baba tarafindan dedesi Carl Gustave Jung'dan almıştır. Bir rivayete göre dede Jung, meşhur Alman şairi Goethe'nin gayrimeşru çocuğudur (Doksat, 2014). Jung'un babası, İsviçre Reformist Kilisesine bağlı bir papaz, annesi ve annesinin ailesi de ilahiyat kökenlidir. Bu sebeple Jung, tıp ve din bilimleri arasında büyümüştür. İlerideki eserlerinde de dinin ve mitlerin etkisi oldukça baskın bir şekilde görülmektedir.

Jung'un gözlerini açtığı Kesswil, geniş çayırlara sahip ancak oldukça az insanın yaşadığı küçük bir kasabadır. Jung'un çocukluğu çayırlarda hayvan otlatarak, akran arkadaşlığından yoksun bir şekilde geçti. İlk kardeşi doğduğunda Jung, çoktan 9 yaşına gelmişti. Geçirdiği yalnız çocukluk yılları Jung'un kendi iç dünyasında düşünsel bir pratik yapmasına, sonrasında geliştireceği kuramlardaki iç görülere ulaşmasını sağlamıştır. Jung annesini güvenilmez ve baskın, babasını ise güvenilir ve güçsüz olarak nitelendirmiştir (Jung, 2001) Annesinin hastalık derecesinde batıl inançlara olan tutkusu, Jung'un babası ile olan evliliklerini zedelemiş ve bu Jung'un büyük teyzesi ve evin hizmetçisi tarafından büyütülmesine sebep olmuştur. Jung'a göre, annesi çift kişilikli bir insandır. Bunlardan ilki zararsız ve insancıl iken "Diğer" olarak tanımladığı kişiliği ürkütücü, dayatıcı ve karanlıktır (Jung, 2001). Bu sebeple Jung çocukluğunda annesine nasıl davranacağını bilememiştir, buna karşılık babasını daha tahmin edilebilir bir kişi olarak tanımlamıştır.

Çocukluğunun hemen ardından gelen okul yılları özelinde Jung kendisini orta karar bir öğrenci olarak nitelendirmiştir. Bu yıllarda bir öğretmeninin Jung'u bir kompozisyon ödevini çalmakla haksız yere suçlaması sınıf arkadaşlarının önünde gururunun kırılmasına, garip biri olarak ötekileştirilmesine ve en sonunda da içinin öğretmene karşı kin ve nefretle dolmasına sebep 


\section{Cem GÜLCAN}

Psikolojik Tipler ve Jung Psikolojisi Üzerine Bir Değerlendirme

olmuştur (Jung, 2001). Bu şekilde geçen eğitim yıllarının ardından Jung, paleontoloji, jeoloji, zooloji ve tarih öncesi arkeoloji gibi alanlara ilgi duymasına karşın bu eğitimlerin kasabasına en yakın şehir olan Basel'de bulunmaması sebebiyle, üniversite için dedesinin de mesleği olan tıp alanını tercih etmiştir. Jung, dedesi gibi cerrah olmak isterken yine maddi sıkıntılar sebebiyle bunu gerçekleştirememiş, Krafft-Ebing'in 'Psikiyatri' adlı kitabı okumasıyla o yıllarda hiç gözde olmadığı gibi geçerliliği de sorgulanan psikoloji alanıyla tanışmış ve ilgi duymaya başlamıştır (Jung, 2006). Bu onun bilimsel hayatına en çok etkisi olan anlardan birisidir. Diğer büyük adım ise Sigmund Freud'la tanışması olmuştur.

Jung, Freud'un adını ilk olarak 1900 yılında basılan "Rüyaların Yorumu (Die Traumdeutung)" kitabıyla duymuş, kitabı okumuş ancak ilk başlarda pek de etkileyici bulmamıştır (Doksat, 2014). Fakat sonrasında Freud'un görüşlerini öylesine güçlü bulmuş, öylesine etkilenmiştir ki ona olan hayranlığı baba-oğul, halef-selef, usta-çırak ilişkisinin yanında Jung’un kendi itirafına göre "Dinsel Bir Tutulma”, "Erotik bir Tını" barındırır hale gelmiştir. Öncesinde mektuplaşmalarla başlayan tanışıklıkları, 1907 yılında Viyana'da bir kongrede yüz yüze gerçekleşmiş ve münasebetleri 1913 yılına kadar yoğun bir şekilde devam etmiştir. Bu tarihten sonra ikili, hem bilim hem de dostluk anlamında bir daha bir araya gelmemişlerdir.

Jung'un ölümü Freud'dan çok daha geç bir tarih olan 1961 yılını bulduğu için yazılı kaynaklarının yanında Jung ile 1957 ve 1959 yıllarında gerçekleştirilen bazı görüntülü röportajlar da günümüze ulaşmıştır. Bu röportajlardan hem Houston Üniversitesi adına Dr. Richard Evans tarafindan 1957 yılında hem de John Freeman isimli televizyon programcisı tarafindan 1959 yılında gerçekleştirilen programda Jung’a Freud ile ilgili pek çok soru yöneltilmiştir (Ümid Gurbanov, 2016; Ümid Gurbanov 2018).

Jung'un bu röportajlardaki beyanlarına göre en başından beri Freud'un görüşleriyle kendi görüşleri arasında temel bazı farklılıklar mevcuttu. Ancak, en özünde ayrıldıkları nokta, Freud'un tüm zihinsel yapının merkezine libidoyu, yani cinselliği koymasıydı. Jung’un “Analitik Psikoloji” kuramına göre libido insan zihnini etkilemekle beraber Freud'un bahsettiği gibi tek ve en güçlü etken değildir. Bunun yanında Freud, gelişim süreçlerinde en önemli dönemi "Çocukluk" dönemi olarak belirtirken, Jung'a göre bu dönem “Orta yaş” dönemidir.

\section{Analitik Psikoloji}

Freud'un kendi görüşlerinin dışındaki görüşlere yönelik kapalı tutumu ve Jung'un eleşirel tavrı, en sonunda Jung'un Freudian ekolden ayrllıp kendi kuramını yaratmasına giden yolu açmıştır. Jung'un kendi öğretilerini bir arada topladı̆̆ “Analitik Psikoloji” kuramı, yeni bir yaklaşım olarak Freud'un psikanaliz kuramının üzerine inşa edilmiştir. Ukray (2014)'a göre Jung, bu noktada Freud'un id, ego, süperego gibi terimlerin terk edip "Psişe” olarak adlandırdı̆̆ $\breve{l}^{2}$ zihni, içerisine 
"Persona, Gölge, Anima ve Animus, Ben (Self) ve Arketipler" gibi yeni kavramlar getirerek açıklamıştır.

\section{Psişe}

“Zihin kavramı, ilk olarak M.Ö. 4.yy’da "Ruh” anlamına gelecek şekilde Sokrates, Platon ve Aristo tarafından felsefenin ortaya çıktığı ilk yıllardan itibaren kullanılmaya başlamıştır" (Rank, 1998, s. 1). Bu yıllardan 19. yy'ın sonuna kadar zihin, yani psişe kavramı ruh ile eş anlamlı şekilde kullanılmıştır.

Jung'un psişesi, en temelinde Şekil 1'de de görüleceği üzere bilinçaltı(bilinçdışı) ve bilinçüstü olmak üzere iki boyuttan oluşmaktadır. Bu iki katman arasında adeta bir süzgeç işlevi gören ego yer almaktadır. Psişe için zararlı olabilecek veya önemsiz derecedeki iletileri bilinçaltına iten ego, diğerlerini bilinç seviyesinde tutar

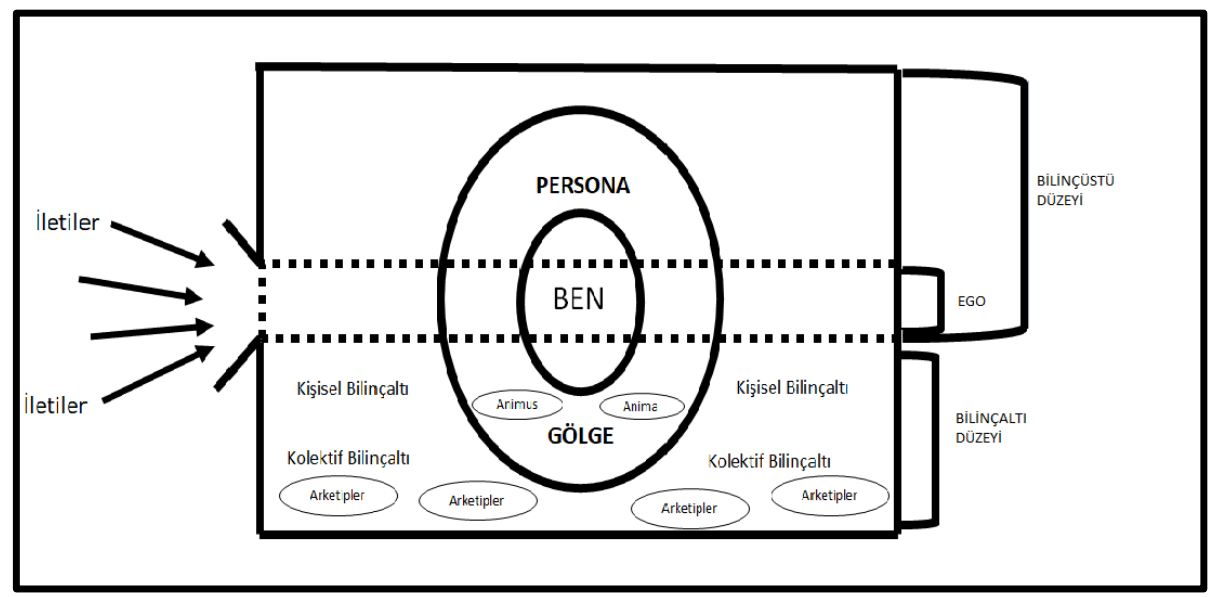

ŞEKİL 1. Jung'un Psişesi, Katmanları ve Ögeler

Kaynak: Jung (2006)'un Analitik Psikoloji kitabından yararlanılarak oluşturulmuştur.

\section{Bilinçaltı ve Bilinçüstü}

"Psikoloji sözlüğünde var olan anlamıyla bilinçaltı; bilinç seviyesinin altında yer alan ve bilinçli olmayan, ancak rastlantı şeklinde kolayca bilinç seviyesine çıkabilen malzemelerin ve süreçlerin olduğu yerdir" (Karaca, 2010, s. 7). Jung, psişeyi bir adaya benzetmiştir. Adanın su altında kalan kısmı, "Bilinçaltı” iken üzerinde kalan kısmı "Bilinçüstü” olarak tanımlanmıştır. Bu iki kavram da literatüre Jung'un kazandırdığı kavramlar değildir. Öncesinde Freud, bilinçaltından bahsetmiş, "Rüyaların Yorumu” adlı kitabında bilinçaltındaki ögelerin rüyalar aracılığıyla ortaya çıktığını belirtmiştir (Numanbayraktaroğlu, 2016). Freud, yalnız bilinçaltı yerine bilinçdışı terimini kullanmıştır. Zihnin süzgecinde yani egoda takılı kalan tecrübeler bilinçaltına veya diğer adıyla bilinçdışına itilirler.

Jung'un Freud'dan ayrıldığı iki temel nokta vardır. Bunlardan ilk noktada Freud, bilinçdışını bilinçten ayırmaz iken Jung, bilinç ve bilinçaltının birbirinden tamamen apayrı 


\section{Cem GÜLCAN}

Psikolojik Tipler ve Jung Psikolojisi Üzerine Bir Değerlendirme

olduğunu savunmaktadır (Karaca, 2010). Diğer ve asıl önemli nokta ise Jung'un bilinçdışını, kişisel bilinçdışı ve kolektif bilinç dışı şeklinde ayırmasıdır (Jung, 2006). Kişisel bilinçdışı, bireyin günlük yaşamda edindiği tecrübeler her türlü kaynaktan aldığ iletilerin ego tarafindan baskılanmasıyla oluşan ögeleri temsil etmektedir. Kolektif bilinçdışında konumlanan "Arketip" kavramı ise pek çoğuna göre Jung'un bilim dünyasına kazandırdığı en özgün yaklaşımdır.

\section{Arketipler}

Jung'un Freud'a getirdiği en temel eleştirilerden birisi, Freud'un bireyin zihninde barındırdığı her şeyin sadece kendi tecrübeleri ile sınırlı olmasıdır. Jung’a göre insanoğlu büyük ölçüde tarihine bağlıdır. Jung'un ifadesi birebir şu şekildedir "Bugünün veya dünün insan değiliz, engin bir çağın insanıyız." Tanımlamak gerekirse arketipler; bireyin zihninin derinliklerinde kişisel deneyim ve anılara dayanmayan, atalarımızdan miras kalan kalıtımsal, evrensel niteliği olan imgelerdir. Jung, arketip adını bulmadan önce "Başlangıçtan beri olan imgeler" ve "Kolektif bilincin hakimleri” ifadelerini kullanıyordu. Daha sonraları Psikolojik Tipler yapıtında da çokça üzerinde durduğu St. Augistinus'tan esinlerek arketip adını bulmuştur (Doksat, 2014). Arketiplerin, Platon'un idealar dünyasıyla kesişen pek çok yanı mevcuttur.

Daha önce de belirtildiği gibi Jung'un üzerinde gerek ailesi gerekse kendi ilgi alanı olması sebebiyle dinin etkisi oldukça büyüktür. Arketiplerin temelinde de mitolojinin ve dinin merkezde olduğunu söylemek gerekir. Bunun yanında Jung'un tarif ettiği pek çok arketip mevcuttur: anne arketipi, gölge arketipi, reenkarnasyon arketipi, aile arketipi gibi.

\section{Persona}

"Persona, bireyin dış dünyaya karşı genel ruhsal davranış biçimidir" (Jung, 2006, s. 39) Buna göre persona, işlevsel bir komplekstir. Bireyin dış dünyada kabul görmek için taktığı, bir nevi maskedir. Jung personayı "Biraz abartmak pahasına da olsa, personanın insanın gerçekte olduğu şey değil, başkalarının ve kendisinin olduğunu düşündüğü şey olduğu söylenebilir”, şeklinde tanımlamıştır.

Persona, psişe için kritik ögelerden birisidir. Bireyin denge halinde olabilmesi için toplum tarafından kabul görmesi aynı zamanda da merkez benliğini kaybetmemesi gerekir. Psişe içerisinde persona çok baskın hale gelirse birey kendisine yabancılaşabilir ve bu nevrotik bir durum yaratabilir. Personanın işlevsiz olması durumunda da birey toplum tarafından uyumsuz ve garip olarak nitelendirilip, ötekileştirilebilir. Jung’un persona kavramını ortaya koymasından çok sonra Erving Goffman'ın “Günlük Yaşamda Benliğin Sunumu” adlı eserinde ortaya çok daha kapsamlı şekilde koyduğu benliğin sunumu, personanın çok daha gelişmiş bir versiyonu olarak değerlendirilebilir (Goffman, 2004). 


\section{Gölge}

Gölge, bireyin “Öteki”, "Karanlık”, "Vahşi” ve "İlkel” yanını temsil etmektedir. "Bireyin içinde yaşadığı toplum ne derece dar ve kısıtlayıcı olursa, gölgesi o kadar geniş olacaktır" (Fordham, 2001, s. 63). Bu olumsuz tanımlamanın yanında gölge, bireyin yaratıcılık tarafına ev sahipliği yapan bir bölge olarak karşımıza çıkmaktadır.

Gölgeyi, Frued'un id kavramına bazı farklılıklar olsa da benzetmek mümkündür. Gölgeyi, baskılayan ve kontrol altında tutan ise psişenin merkezindeki egodur. Bazı durumlarda ego saf dışı kalabilir ve gölge bireyin tutum ve davranışlarına yansıyabilir. "Ne olduğunu anlamadım her şey birden gelişti”, “O kadar sinirlendim ki gözüm kararmış” dediğimiz durumlara sebep gölgenin bilinçaltından bilinç düzeyine çıkmasıdır. Gölge, bireyin bir parçasıdır, varlığının kopmuş bir bölümüdür; ancak kopmuş dahi olsa kişinin gölgesi yine ona bağl1 kalır (Jung, 2006).

\section{Anima ve Animus}

Jung'a göre hiçbir insan tamamen erkek ya da kadın değildir. Her erkeğin içinde bir kadın, her kadının içinde de erkek arketipleri mevcuttur. Bunlardan erkek birey içindeki kadın arketipi, "Anima" olarak adlandırılırken, kadın içindeki erkek de "Animus" olarak adlandırılmıştır. Bu arketipler bireyin karşı cinsle olan iletişiminin başarısı ve sosyalleşmesi için en önemli arketiplerdir.

Anima ve animus kavramlarının özünde şu temel varsayım vardır. Animus, kalıpsal olarak duygusal ve anaçtır; erkeklerin geleneksel olarak mantık, güç cesaret, liderlik, entelektüel akı1, fiziksel güç gibi eril özelliklerini yansıtır (Sharf, 2014). “Anima ise duyarlılık, duygusal akıl, sezgi, duygudaşl1k ve özen gibi dişil güçleri temsil eder" (Indick, 2011, s. 145; aktaran: Derin ve Acar, 2016, s. 455). Tüm bunların yanında Anima veya Animusun psişe içerisinde fazla benimsenip baskın hale gelmesi, bireyin kendi cinsiyetiyle çelişen bir hale gelmesine ve nevrotik bir duruma sürüklenmesine sebep olabilir.

\section{Ben (Self)}

Ben, Şekil 1'de de görüldüğü gibi psişenin merkezinde yer alır ve bilinçaltı ile bilinçüstünü senkronize şekilde birlikte yürütür. Benlik, psişenin merkezinde yer aldığ 1 gibi psişenin tümünü temsil eden bir öz olarak da tanımlanabilir. Ben yüzeysel olarak tamamen personayla örtülüdür, bu sebeple bireyin sosyal çevresinde yarattığ imajlar ben ile tamamen benzeşmez. Ancak bireyin en saf hali olan Ben'ine ters düşecek şekilde uzun süre davranması özellikle orta yaşlara gelindiğinde ciddi ruhsal bozukluklara yol açabilir (Jung, 2006).

İnsanın psişesi homojen bir yapıda değildir. Psişe içerisinde birbirine zıt veya birbiriyle çelişen yapı gelişigüzel ve dağınık bir biçimde bulunmaktadır. Ben, bu birbiriyle aynı frekansta olmayan ögeleri bir araya getirip ortak bir melodide buluşturan, tutarlı bir bireyin ortaya çıkması için zihni toparlayan kısımdır. Çünkü Ben'in esas yükümlüğü kişinin, bireyselleşme sürecini 


\section{Cem GÜLCAN}

Psikolojik Tipler ve Jung Psikolojisi Üzerine Bir Değerlendirme

tamamlamış, olgun ve sağlıklı bir psişeye sahip bir kimse olmasını sağlamaktır. Ben'in bütüncül bir şekilde yorumlanması sonucunda kişilik yapıları Jung tarafından bazı sınıflandırmalara tabi tutulmuştur. Jung'un "Psikolojik Tipler" olarak adlandırdığı yapı doğrudan ben kavramıyla ilintilidir.

\section{Psikolojik Tipler}

Jung, Psikolojide Tipler çalışmasını “Anılar, Düşler ve Düşünceler (Jung, 2001)” isimli otobiyografisinin, altıncı ve yedinci bölümlerinde anlattı̆̆ "Kendi Psişesini Anlama Çabası" üzerine kurmuştur (Jung, 2019). Daha önce de bahsedildiği gibi, Jung yalnız bir çocukluk geçirirken derin düşüncelere dalarak, çevresindeki insanları ve en başta da kendini yorumlamayı bir huy haline getirmiştir. Jung, bu konuda Psikolojik Tipler kitabının birinci baskısının önsözünde şu cümleleri kurmuştur (Jung, 2019, s. 11):

"Bu kitap pratik psikoloji alanında yaklaşık yirmi yıllık çalışmamın meyvesi. Sinir hastalarının tedavisinde bir psikiyatrın sayısız izlenimlerinden ve tecrübelerinden, her sosyal düzeyden kadın ve erkekle görüşmelerinden, dost ve düşmanla kişisel ilişkilerimden, son olarak da kendi psikolojik tuhaflığımın eleştirisinden biçimlenerek düşüncelerimde yavaş yavaş gelişti."

Jung'un öğretileri oldukça karmaşık bir yapıda olmasına karşın bu kitap onun pratik psikoloji dediği, günlük yaşama katkı yapmak amacıyla ortaya koyduğu bir tipoloji çalışmasıdır. Yine buna olarak paralel Jung, bu sınıflandırmayı ortaya koymasındaki temel amacını, tarihsel bir gerekçe ihtiyacından daha çok kendi tecrübelerini yalnız bu alanla ilgilenenlerin değil, iyi eğitimli ve bu meslekten olmayan herhangi birinin yarar sağlayabileceği bir bağlam oluşturmak olduğunu belirtmiştir (Jung, 2019). Jung bu tipolojiyle bireyi, en temelde "İçe Dönük" ve "Dışa Dönük" olmak üzere ve bu her tipin altında da "Duyusal", "Duygusal", "Duyumsal" ve "Sezgisel" olmak üzere toplamda 8 farklı sınıfa ayırır. Bu makalede de Jung'un "Psikolojik Tipler" kitabındaki betimlemelere dayanılarak her sınıf örneklendirilerek aktarılmaya çalışılmıştır.

\section{İçe Dönük Düşünen Tip ve Albert Einstein}

Newton'un ortaya koyduğu fizik ve mekanik kurallar, 17.yy'ın sonlarından 20.yy'ın başlarına kadar test edildiği her sınavdan başarıyla geçmiştir. Hala da dünya üzerinde yapılan pek çok çalışmanın temelinde, Newton'un fiziği yatmaktadır. Ancak Einsten'ın ortaya attığı Özel ve Genel Görelilik kuramları Newton'un yanıldığını, onun Klasik Fizik de denilen öğretilerinin 1şık hızına yaklaşıldığında veya uzay-zaman denkleminde çalışmadığını ortaya koymuştur. Einstein, bu kuramları yaratırken bunu tümüyle zihinsel bir süreçle gerçekleştirmiş, ne bir deneye ne bir gözleme ne de matematiksel bir denkleme dayandırmıştır. Einstein tüm kuramı zihninin içinde yaratmış, geliştirmiş ve bütünleştirmiştir. Bunun ardından kuramın matematiksel denklemi ortaya konmuş ve en sonunda da İngiliz astronom Arthur Stanley Eddington tarafindan test edilerek 
kanıtlanmıştır. Eğer Einstein, bu kuramları zihninde yaratarak ortaya koymasaydı hiçbir zaman bu özgünlükte bir yaklaşım geliştirilemeyeceği muhtemeldir.

Einstein'ın İçe Dönük Düşünen Tip sınıfına girmesindeki en temel sebep, yukarıda da bahsedildiği gibi en başında kuramını ne bir gözleme ne de başka bir fiziksel kanıta dayanarak oluşturmamasıdır. Tüm süreç Einsten'ın “İç” zihinsel dünyasında yaratılmıştır. İçe Dönük Düşünen Tipler, araştırma yapmak için yalnız başlarına kalmayı ve düşüncelerini genellikle kendilerine saklamayı tercih ederler. Diğer insanların ne yaptıklarıyla pek ilgilenmezler, gururlu ve inatçıdırlar. Düşünceleri çağdaşlarının çok ilerisinde olduğu için, diğer insanlar onları anlamayabilirler ve bu sebeple genellikle bu tipler fikirlerini kendilerine saklamayı tercih ederler. Mesleki olarak örneklendirmek gerekirse, dış dünyayı zihinlerinde sorgulayan, sık sıł zihinsel muhasebeler yapan filozoflar bu tipi iyi temsil ederler.

\section{Dışa Dönük Düşünen Tip ve Charles Darwin}

Charles Darwin, 1835 yılında Galapagos takımadalarına ayak bastığında 26 yaşındaydı. Adaya geldiğinde onu müthiş çeşitli ve bol miktarda, diğer bölgelerde bulunmayan bitki ve hayvan türleri karşılamıştı. Böylece bu adalarda, küçük bir alanda bulunan değişik habitatları inceleyebilmiş, adaların farklı kesimlerinden farklı örnekler toplamıştır. Tüm bu örnekleri inceleyerek buradaki türlerin, diğer bölgelerdekilerden farklılaşan özelliklerini tespit etmiş ve bunun sonucunda meşhur "Evrim Teorisi” ortaya atılmıştır.

İşte Darwin'in dışa dönük yaptığı bu gözlemler, onu Dışa Dönük Düşünen Tip’e iyi bir örnek yapmaktadır. "Jung'a göre bu tipler, faaliyetlerini entelektüel sonuçlara bağlamaya meyillidirler ve bu sonuçları nesnel verilere, olgulara ya da fikirlere dayandırmaya çalışırlar" (Jung, 2019, s. 366). Hayatlarında belirli idealleri vardır ve bu idealler olmadan var olamazlar. Diğer insanlar tarafından hemen her konuda kolay ikna edilemezler. İkna olmaları için geçerliliği olan, elle tutulabilir ve sınanabilir veriler gereklidir. Yine Jung'a göre Dışa Dönük Tip'in düşünüşü ortaya yararlı ve olumlu yeni olguların çıkmasına sebep olur (Jung, 2019).

\section{İçe Dönük Duygusal (Hisseden) Tip ve Franz Kafka}

Franz Kafka, 1924 yılının Haziran ayında, 40 gibi genç bir yaşta akciğer kanseri sebebiyle ölürken, bugün Dünya üzerindeki popülaritesini hayal bile edememişti. Hatta öyle ki yaşamı boyunca bir eserini bile basılmaya layık görmemiştir. Kafka, ölmeden kısa süre önce en yakın arkadaşı Max Brood'a tüm eserlerini yakmasını vasiyet etse de o bunu yapmayıp Dünya edebiyatına Kafka'yı kazandırmayı, arkadaşına olan sözünü tutmaya tercih etmiştir. Kafka'nın bu tutumumun temel sebebi ise eserlerini yeteri kadar iyi bulmaması ve okumaya değer bulmamasından kaynaklıdır. Kısacası Kafka, haddinden fazla mükemmeliyetçi ve özgüvensiz bir kişiydi. İşte bu özellikleri Kafka’yı İçe Dönük Duygusal tip için güzel bir örnek yapmaktadır. 


\section{Cem GÜLCAN}

Psikolojik Tipler ve Jung Psikolojisi Üzerine Bir Değerlendirme

$\mathrm{Bu}$ tiplerin toplumu değiştirmek, dönüştürmek veya etkilemek gibi bir amaçları yoktur. Onlar için hissetmek üzerinden kazanç bir şey değildir. Sanat veya yaptıkları hisse dayalı her faaliyet onlar için olağandır. Sanatları, genelde doğadan veya çevreden esinlenmek yerine hayal dünyasından gelir. Kafka’nın meşhur eseri “Dönüşüm” akıllara getirildiğinde, Gregor Samsa'nın bir sabah uyandığında kendisini bir böcek olarak bulması fikrinin, tamamen bir zihinsel yaratıcılık sonucu olduğu hatırlanacaktır.

Jung, İçe Dönük Hisseden Tip'i genellikle kadınlarda daha çok gördüğünü belirtmiş ve "Durgun Sular Derin Akar” atasözünün kadınları iyi tasvir ettiğinden bahsetmiş̧tir. Yine bu tipin, hayran bırakma, dışarıya tesir etme, etkileme veya herhangi şekilde değişimi arzu etmeksizin hoş bir huzur ve sempatiklik içerisinde yaşadığını ortaya koymuştur (Jung, 2019). Bu tipler, oldukça soğuk ve mesafeli gözüktüklerinden dışarıdan insanlar tarafından duygusuz olarak damgalanabilirler. Ancak, bu kanı oldukça yanlıştır. Hisleri daha derinde ve diğer insanlara göre oldukça yoğun şekilde gelişir. Bu tipler iyi edebiyatçı, söz yazarı, bestekâr veya derin hislerin vücut bulduğu her türlü sanatı icra eden bir sanatçı olabilirler.

\section{Dışa Dönük Duygusal (Hisseden) Tip ve Salvador Dali}

Jung'un tecrübelerine göre en bariz duygusal (hisseden) tipler genellikle kadınlardan çıkar. Jung, dışa dönük olanların örneklerine de ezici çoğunlukla kadınlarda tespit ettiğini belirtmiştir (Jung, 2019). Bu tip bireyler, ömürleri boyunca hislerini pusula olarak kullanırlar. İçe Dönük Duygusal Tiplerden farklılıklarına bakıldığında ise duygularını coşkulu yaşamaları, insanlarla paylaşma eğilimleri, yalnızlıktan ve depresiflikten hoşlanmamaları şeklinde sıralama yapılabilir. Bunun yanı sıra duygularını kendilerine hem maddi hem manevi anlamda avantaj sağlayacak şekilde kullanmaktan çekinmezler. Yeteneklerinin farkındadırlar ve bunu kazanca kolaylıkla çevirebilirler. Sosyal sermayeleri onlar için inanılmaz önemlidir, yalnızlık onlar için inanılmaz korkutucudur. Lükse ve şatafata düşkündürler, tüm bunları çevrelerinde itibar sahibi olmak için araç olarak kullanabilirler.

Tüm bu sayılan özelliklerin neredeyse tümünün vücut bulduğu isim ünlü sürrealist ressam Salvador Dali'den başkası değildir. Dali'yle kişisel olarak tanışıklığı olan hemen herkes onun ya deli olduğunu ya da deli taklidi yaptığını düşünmüştür. Dali'nin sanatı bir yana ona dünya genelindeki şöhretini kazandıran yegâne şey onun magazinsel yanıdır. Dali paraya da oldukça kıymet vermiştir. Her daim sanatı üzerinden elde edebileceği en yüksek maddi kazancın peşinde koşmuştur. Bir rivayete göre tablolarındaki yüksek fiyatların nedenini zengin müşterilerine açıklarken Dali, içinde yılan zehri bulunan boyalar kullandığını belirtiyordu. Hatta gittiği pahalı restoranlarda hesap ödeme aşamasında eline bir çek defteri alıp, üzerine gereken miktarı yazmak yerine arkasına bir karikatür çizip ödeme olarak bunu veriyor, bu durumda hem Dali hem de 
restoranlar kazanç sağlıyordu. İște Dışa Dönük Hisseden Tipler de tam olarak bu şekilde hareket etmekten çekinmezler.

\section{İçe Dönük Duyumsal Tip ve John Berger}

$\mathrm{Bu}$ bireyler, nesneden çok nesne ile ilgili algılamalara odaklanan, görünenden çok görünenin ardındaki anlama önem veren tiplerdir. Yerel değil, küresel kişilerdir. Yetiştikleri toplumun kültürlerinin, geleneklerinin, göreneklerinin, ön yargılarının ve yüklediği diğer tüm kalıplardan sıyrılmışlardır. Jung, Duyumsal tip ile ilgili şu cümleyi kuruyor: “Örneğin çok sayıda ressam aynı manzaranın resmini yaptığında her biri onu aslına sadık olarak çoğaltır ama her resim diğerlerinden farklı olur, farkların nedeni hem yetenek hem de daha çok görme yollarıdır” (Jung, 2019, s. 411). Duyusal tip, tam da bu noktada diğer insanlardan farklı noktaları görme, görünenin ardındakini "duyumsama” özetle görme biçimleri bakımından ayrışmaktadırlar.

Bu tipe en iyi örneklerden birisi İngiliz sanat eleştirmeni ve meşhur "Görme Biçimleri" kitabının yazarı John Berger'dir. (Bergerb, 2008, s. 7) Görme Biçimleri kitabına şu sözlerle başlamıştır:

“Her akşam güneşin batışını görürüz, Dünya'nın Güneş’e arkasını dönmekte olduğunu biliriz. Ne var ki bu bilgi, gördüklerimizle uymaz hiçbir zaman. Gerçeküstücü ressam Magritte "Düşlerin Anahtarı" adlı resminde sözcüklerle görülen nesneler arasında her zaman var olan bir uçurumu yorumlamıştır."

Bu tipler, düşüncelerinin, hislerinin ve sezgilerinin önüne somut gerçekliğe dayanan ama gömülmüş duyumsamalarını koyarlar. Estetik ve stil konuları ilgi alanı olduğu için bu tip genel itibariyle sanat ve müzik alanlarında kendini ifade edebilmektedir. Sanat eleştirmenleri, bu grubun içine girerler. Disiplinli, çalışkan, sabırlı ve titizlerdir.

\section{Dışa Dönük Duyumsal Tip ve Niccolò Machiavelli}

Jung, bu tipi tarif ederken, hiçbir insan tipi gerçeklikte Dışa Dönük Duyumsal Tip'inin dengi olamaz ifadesini kullanmıştır (Jung, 2019). Bu ifadede de açık şekilde görüleceği gibi bu tipler için nesnel olgulara karşı olan duyular inanılmaz gelişkindir. Onlar için tecrübeler ve bu tecrübelerin sağlayacağı faydalar önemlidir. Fayda sağlamayan bilgi veya herhangi şey zaman kaybıdır. Görünenin ardında anlam aramak, soyut kavramlarla uğraşmak beyhude çabadır ve sonuç odaklı olmak en doğru harekettir. Detaylardan hoşlanırlar ve soyutlamalara, değerlere veya anlamlara ayıracak pek fazla vakitleri yoktur.

Rönesans, her alanda realizmin tavan yaptığı bir dönemdir. Bu dönemde doğayı en iyi tasvir eden ressam en iyi ressam, heykeli aslına en çok benzeten heykeltraş en iyi heykeltraş ve insan ilişkilerini en gerçek şekilde yorumlayan en iyi toplumsal düşünür olarak görülmüştür. $\mathrm{Bu}$

dönemde Rönesans'ın kalbinde, Floransa'da yetişen Nicolo Machiavelli, realist olarak tanımlayacağımız bu tip için ideal bir örnek oluşturur. Machiavelli'nin meşhur eseri 


\section{Cem GÜLCAN}

Psikolojik Tipler ve Jung Psikolojisi Üzerine Bir Değerlendirme

"Hükümdar", siyaset tarihine damga vurması bir kenara, dönemin Floransa hükümdarı Lorenzo De Medici'ye tavsiye ettiği yöntemlerin zalimliği sebebiyle de geniş bir şöhrete sahiptir. Machiavelli için siyaset kurumunda devlet adına başarı için atılan her adım ne kadar ahlaksızca veya zalimce olursa olsun sonuç getiriyorsa en iyidir, mubahtır (Machiavelli, 2019). Ona göre en iyi kumandan, sinsilikleri ve oyunları en iyi bilim kumandandır.

İşte Dışa Dönük Duyumsayan Tip de tam olarak bu şekilde her durumdan faydayı gözetirler. Bu sebeple dışarıdan ruhsuz, yapay veya duygusuz olarak görülebilirler. İyi tüccar, devlet adamı veya iş insanı olmaları muhtemeldir.

\section{İçe Dönük Sezgisel Tip ve Nostradamus}

Jung'a göre bu tip, tarifi en zor olan psikolojik tiptir. "Bu tipler gizemli, hayalci ve kâhin olmalarının yanında sanatsal ve tuhaf kişiler olarak da tanımlanmışlardır.” (Jung, 2019, s. 418)

Eğer sanatçı olurlarsa tuhaf ve anlaşılması güç eserler ortaya koyan biri, olmazlarsa hata yapmış büyük bir adam veyahut bir bilge olarak görülebilirler. Dünyayı algılama şekilleri fanteziktir, eğer görüşlerini açıklamaya kalkışırlarsa deli olarak görülebilirler. Bu tipler için nesnel duyumlar önemsizdir. Sezgiler tecrübelere dayanmaz, bilinçdışının a priorilerine (Öncel Bilgi) bağlıdırlar. İçedönük sezgisel tip, dışadönük sezgisel tipin aksine gerçek dünyada yer almayan, soyut, hayalî bir anlamda öznel ve tuhaf olarak değerlendirilen konularla ilgilenmektedir.

Bu tipe örnek vermek de tanımlamak kadar zor olsa da ünlü kâhin Nostradamus, Jung’un tanımlamalarından yola çıkılarak verilebilecek örneklerden iyi bir tanesi olarak gözükmektedir. Hakkındaki bilgiler her ne kadar belli miktarda magazinsel ve nesnellikten uzak olsa da bu durum ortadaki Nostradamus imgesini tipolojik olarak yorumlanmasına engel değildir. Nostradamus, 2 Temmuz 1566'da Franciscan Manastırında ölmüştür. Bir rivayete göre ölmeden önceki son gecesinde yanına gelenlere şu sözleri söylemiştir: "Bu son gecem, beni yalnız bırakın, zira sabaha ölmüş olacağım." Bu olayın doğruluğunu bir kenara bırakıp genel çerçeveden baktığımızda, Nostradamus'un bu öngörüye düşünerek, duyumsayarak veya hissederek değil sezinleyerek ulaştığını söyleyebiliriz. Sezgiler, bu tipler için diğer bütün tecrübelerden üstün ve yol göstericidirler. Kâhinler, medyumlar, keşişler, metafizik düşünürler ve hatta peygamberler bu tiplere örnektirler.

\section{Dışa Dönük Sezgisel Tip ve Adolf Hitler}

$\mathrm{Bu}$ tipi, İçe Dönük Sezgisel Tip’ten ayıran en temel özellikleri “Gerçeği” zihin dünyasında değil gerçek Dünya'da aramalarıdır. Bu tipteki insanlar, nesnel gerçeklikle başa çıkmak için genellikle sezgilerini kullanırlar. Yenilikten ve değişimden çekinmezler ve imkânsız nedir bilmezler. Haddinden fazla cesurdurlar. Fakat muhakeme yetenekleri düşünce ve duyuma dayanmak yerine sezgi temelli olduğu için oldukça zayıftır. Karşılarındakileri etkileme güçleri 
oldukça yüksektir. Dolayısıyla ikna kabiliyetleri de oldukça fazladır. Toplumları harekete geçirmekte ustadırlar ancak başkalarının iyiliğini yeterince gözetmezler (Jung, 2019). Bu sebeple, tehlikeli sonuçlara sebebiyet verebilirler.

Adolf Hitler, 30 Nisan 1945 ’te saklandığı sığınakta öldüğünde onun başlattığg İkinci Dünya Savaşı'ndaki ölümlerin toplamı 60 milyonu çoktan geçmişti. Hitler'i basit bir onbaşı olmaktan çıkarıp bir ulusu toptan, çılgınca bir saldırganlığa ve tüm dünyayı da bir bataklığa sürükleme yetisine sahip bir lidere dönüştüren şey çevresindekileri etkileme gücüydü. Hitler, iyi bir hatipti ve Birinci Dünya Savaşı'nın ağır yaptırımları altında ezilmiş Alman halkı kolayca onun cesur ve pervasız tavrından etkilenmişti.

Bu tipler, Hitler örneğinde de görüldüğü gibi realist değildirler. Bağımsız olma eğilimleri vardır ve kontrol edilmeye direnç gösterirler. Evlilikleri genellikle başarısız olur. Yaratıcı bir karaktere sahip olan bu tip sahip olduğu fikirleri anlık kararlarla değiştirebilecek cesarete sahip, macera arayışı içerisinde cesur bir tiptir. Attıkları cesur ve akla dayanmayan adımlar sonuç verirse deha-kahraman, vermezse ahmak olarak görülürler. Reklamcı, siyasetçi olabilirler.

\section{Sonuç}

Jung, pek çok açıdan eleştirilmesine karşın 20. yüzyılın en büyük sosyal bilimcileri arasında yerini almış ve ardından gelen pek çok yeni bakış açısına temel oluşturmuştur. Psikolojik tipler sınıflandırmasını ortaya atarken aslında Jung, hiçbir insanın tamamen bir tipe kusursuz bir şekilde uymayacağının ön bilgisini vermiştir. Ancak psikolojik tipler, Jung'un da tarif ettiği Pratik psikoloji alanı içinde, günlük yaşama katkı verebilecek, sonuç odaklı ve belirli frekansın üstündeki her insanın anlayabileceği bir yaklaşım olarak literatürde yerini almıştır.

Bu çalışmayla da Jung'un öğretileri bir araya getirilmeye, özellikle de psikolojik tipler yaklaşımı, Jung kutup alınarak yapılan betimlemelerle ve örneklendirmelerle daha açık hale getirmeye çalışılmıştır. Yine unutulmamalıdır ki örneğin; bir insanın İçe Dönük Düşünsel tip olması için Einstein veya Dışa Dönük Duygusal Tip olması için Salvador Dali olması gerekmez. Aynı şekilde Dışa dönük Sezgisel Tip olmanızın sizi Hitler gibi cani yapmayacağı gibi İçe Dönük Sezgisel Tip olmanız sizi kâhin, medyum veya mistik bir şahsiyet yapmaz. Toplum içinde her bireyin, kendi zihnini kullanış biçimi, dünyayı algılama yöntemi onun psikolojik sınıfını belirler.

\section{Kaynakça}

Berger, J. (2008). Görme Biçimleri, Çeviren: Yurdanul Salman, 14. Baskı, İstanbul: Metis Kitap.

Derin, S. ve Acar, N. (2016). Analitik Terapi Bağlamında Film Analizi: Tehlikeli İlişki A Movıe Analysis Withın The Context Of Analytical Therapy: The Dangerous Method, Uluslararası Sosyal Araştırmalar Dergisi The Journal of International Social Research, $9(45)$. 


\section{Cem GÜLCAN}

Psikolojik Tipler ve Jung Psikolojisi Üzerine Bir Değerlendirme

Doksat, K. (2014), Psikiyatri Tarihi 1860-1960, Ankara: Alter Yayıncıl1k.

Jung, C.G. (2001). Anılar, Düşler, Düşünceler: Otobiyografi, Yayına Hazırlayan: Aniela Jaffe,

Çeviri: İris Kantemir, İstanbul: Can Yayınları.

Jung, C.G. (2006). Analitik Psikoloji, Çeviren: Ender Gürol, İstanbul: Payel Yayınları.

Jung, C.G. (2019). Psikolojik Tipler, Psikanaliz Serisi 4, Çeviren: Nur Nirven, İstanbul: Pinhan Yayıncilik.

Fordham, F. (2001). Jung Psikolojisinin Ana Hatları. İstanbul: Say Yayınları.

Goffman, E. (2004). Günlük Yaşamda Benliğin Sunumu, Çeviren: Barış Cezar, 3. Basım, İstanbul: Metis Yayıncılık.

Indick, W. (2011). Senaryo Yazarları İçin Psikoloji, Çev. E.Yılmaz ve Y. Karaarslan, 2. Baskı, İstanbul: Agora Kitaplığı.

Karaca, H.E. (2010). Resimde Bilinç Dışı Anlatımın Rastlantısal ve Deneysel Süreci. Yüksek Lisans Tezi, Gazi Üniversitesi, Ankara.

Machiavelli, N. (2019). Hükümdar, Çeviren: Necdet Atabăg, Hasan Ali Yücel Klasikler Serisi, 18. Basım, İstanbul: Türkiye İş Bankası Kültür Yayınları.

Numanbayraktaroğlu, S. (2016). Zor Sanat: RüYa Yorumu; Freud'un Evrensel Rüya Simgelerinin Göstergebilim Ve Sosyal İnşacı Benlik Kuramları Açısından Eleştirel Bir İncelemesi. Doğu Batı Dergisi, Rüyalar Sayıs1 76, 67-89.

Rank, O. (1998). Psychology and the Soul, London: The Johns Hopkins University Press.

Sharf, S.S. (2014). Psikoterapi ve Psikolojik Danışma Kuramları, Çev Ed.: Nilüfer Voltan Acar, Ankara: Nobel Akademik Yayıncılık.

Ukray, M. (2014). Jung psikolojisi. Ankara: Yason Yayınları.

Ümid Gurbanov (2016, Şubat 28). Jung on Film (1957) | Türkçe Altyazıl1, [Video], YouTube. https://www.youtube.com/watch?v=8CXHIEeMMEw\&t=2118s\&ab_channel=\%C3\% 9CmidGurbanov

Ümid Gurbanov. (2018, Şubat 24). Carl Gustav Jung: Face to Face (BBC-1959) | Türkçe Altyazılı (Eng Sub), [Video], YouTube.

https://www.youtube.com/watch?v=7SaJrWV_qss\&t=1382s\&ab_channel=\%C3\%9CmidGurba nov 